\title{
An Assessment of Fracture Resistance of three Composite Resin Core build-up Materials on three Prefabricated Non- metallic Posts, Cemented in Endodontically Treated Teeth: An in Vitro Study
}

Lalit Kumar, Bhupinder Pal, Prashant Pujari

Endodontically treated teeth with excessive loss of tooth structure would require to be restored with post and core to enhance the strength and durability of the tooth and to achieve retention for the restoration. The non-metallic posts have a superior aesthetic quality. Various core build up materials can be used to build-up cores on the posts placed in endodontically treated teeth. These materials would show variation in their bonding with the non-metallic posts thus affecting the strength and resistance to fracture of the remaining tooth structure.

Aims: The aim of the study was to assess the fracture resistance of three composite resin core build-up materials on three prefabricated non-metallic posts, cemented in extracted endodontically treated teeth.

Material and methods: Forty five freshly extracted maxillary central incisors of approximately of the same size and shape were selected for the study. They were divided randomly into 3 groups of 15 each depending on the types of non-metallic posts used. Each group was further divided into 3 groups ( $A, B$ and $C$ ) of 5 samples each depending on three core build-up material used. "EStudent's unpaired ' $t$ ' test was also used to analyse and compare each group with the other groups individually, and decide whether their comparisons were statistically significant.

Results: Luxacore showed the highest fracture resistance among the three core build-up materials with all the three posts systems. Ti-core had intermediate values of fracture resistance and Lumiglass had least values of fracture resistance. 
2 An Assessment Of Fracture Resistance Of Three Composite Resin Core Build-Up

3 Materials On Three Prefabricated Non-Metallic Posts, Cemented In Endodontically Treated

4 Teeth. -An In-Vitro Study

5 Contributors

6 1. Dr.Lalit Kumar

M.D.S

Associate Professor,

Department Of Prosthodontics

Dr.Harvansh Singh Judge Institute of Dental Sciences and Hospital,

Panjab University, Chandigarh, India

12

2. Dr. Bhupinder Pal

4

$$
\text { M.D.S }
$$

Consultant Maxillofacial Prosthodontist\&Implantologist,

$$
\text { BARNALA, PUNJAB, India }
$$

3. Dr. PrashantPujari

$$
\text { M.D.S }
$$

Reader

Department of Orthodontics

Pacific Dental College,Udaipur, Rajasthan, India

\section{Corresponding Author:}

Dr.Lalit Kumar 


\section{Introduction}

Aesthetics demands as well as awareness of patients have increased over the years.

34 Combination of new generation materials with improved clinical procedures has opened more avenues

35 for both the dentist and the patient. Tooth coloured materials in dentistry have progressed to the point where they can now be used confidently in almost every restorative situation.

Dental treatment and techniques have evolved from "removing the infected tooth" to "treating the infected tooth." Endodontic therapy has transversed a meandering course, and in the present day scenario a grossly decayed tooth with lost crown structure is effectively used to support a restoration and thereby restoring function, aesthetics, and psychological comfort for the patient. Special techniques and consideration are needed to restore such mutilated teeth to have a good prognosis (Fernandes AS, Dessai GS, 2001).

The loss of considerable amount of tooth structure makes retention of subsequent restorations more problematic and increases the likelihood of fracture during functional loading. Different clinical techniques have been proposed to solve these problems, and one such technique is the post and core. The basic objective in restoring mutilated teeth with post and core, is the replacement of the missing tooth structure to gain adequate retention for the final restoration (Trabert KC, Cooney JP, 1984)

Dentistry has evolved with technological progress. With rapid research and development in the different instrumentation, post and core systems, are easier than even before. Foundation restoration as they are known today, form the base for attachments for crowns, bridges and other prosthesis (Morgano SM, Brackett SE, 1999).

In the earlier years dowel crowns as they were known were fabricated to restore endodontically treated teeth where a considerable amount of tooth structure was lost. However they were difficult to replace, as they could not be removed easily from the root canal without fracturing the root. With advances in restoring endodontically treated teeth, the post and core system has gained popularity to build the lost tooth structure. The post engaged the radicular dentin to achieve retention and the core replaced the coronal portion of the crown. This could be fabricated in metal as one piece casted restoration or could be a separate post with a core build up. 
2

Various materials for posts have been introduced. To achieve the best results the post material should have physical properties similar to dentin, it should bond to the tooth structure and be biologically compatible (Assif D, et al. 1989; King PA, Setchell DJ, 1990). Posts are made mostly of various corrosion resistant metals, which are rigid. The cast post and core has been widely used in restorations, but however its stiffness has always increased the risk of stress concentration leading to root fracture. Custom cast post would also compromise aesthetics as a grey tint of the metal may show through the thin root walls. The type of crown material does affect the post selection (Fernandes AS, Shetty S, Coutinho I. 2003). The growing demand for esthetic restorations has led to the development of tooth coloured, metal free posts which have elastic modulus comparable to dentin which prevents the tooth from fracture, potentially allowing for retreatment of the tooth and better aesthetics (Shetty T, Bhat S, Shetty P, 2005).

Cores are built using metallic or non-metallic materials. In earlier years amalgam was popular, later cements like glass ionomer and modified ionomers were used and now improved high strength composite resins are being used to build cores (Cohen S, Burns RC, 1994). With the advent of metal free dentistry to achieve optimum aesthetics, tooth coloured non-metallic post like glass fiber, quartz fiber, zirconia, ceramic have become popular. They can be used with various composite resin core build-up materials.

Composite resin core materials are used in conjunction with non-metallic posts in restoring endodontically treated anterior teeth to achieve better aesthetics. Thus the prefabricated non-metallic posts with composite resin core built-ups have gained popularity in the recent years. A variety of these systems are available. With this background in mind an in-vitro study was planned to assess and compare the fracture resistance of composite resin core build-up materials with non-metallic posts in extracted endodontically treated teeth.

(a)
approximately similar size and shape, those free of cracks, caries and fractures were selected. Ethical clearance was obtained from Ethical board of the institution to use extracted teeth for the purpose of this study. 
Extracted teeth were scaled to remove calculus and hard debris with an ultrasonic scaler. They were then stored in saline until use. The labial and palatal surfaces were marked.

The 45 central incisors were divided randomly into 3 groups of 15 each depending on the types of non-metallic posts used. Depending on the core build-up material each group was further divided into 3 groups (A, B and C) of 5 samples each. Since there were 3 types of posts and 3 different core materials, there were a total of 9 subgroups having 5 samples each. (Table-1)

\subsection{Post Systems used:}

\section{i) Glass fiber post - Reforpost by Angelus Dental solutions (Brazil).}

These are glass fiber posts. They are composed of prefabricated posts made from glass fibers embedded in epoxy resins for intra-radicular reinforcement. They are non silanated and it was required to silane them. A post of diameter 1.1 was selected.

\section{ii) Quartz fiber posts - D.T. Light posts by RTD (France)}

They have unidirectional pre-tensed quartz fibers in epoxy matrix using a modified resin that wets the fibers creating a translucent effect. It has double taper. They are non silanated. A post of diameter $1.2 \mathrm{~mm}$ was selected.

\section{iii) Zirconia post - Snow light posts by Danville}

High percent of Silica Zirconia fibers embedded in the polyester matrix for strength with flexibility close to natural dentin. They are high light transmissive and white in colour, presilanated, and higher filler ratio of $60 \%$. A post of diameter $1.2 \mathrm{~mm}$ was selected.

\subsection{Materials used for Core build-ups:}

\section{i. Composite resin dual cured core build-up - Luxacore by DMG (Dental Avenue India)}

It is composed of Barium glass $69 \%$, PyrogSilica 3\% in BIS GMA matrix. Filler by weight is $72 \%$ and filler particle size is 0.02 to $4 \mathrm{~mm}$. It is radio-opaque.

\footnotetext{
ii. Composite resin Light cured core build-up- Lumiglass by RTD France (by Prime Dental India).
} 
It consists of hybrid BISGMA composite resin. Filler by weight is $80 \%$ and filler particle size is $2-5 \mathrm{~mm}$. It is radio-opaque.

\section{iii. Composite resin self cured core build-up - Ti-Core natural by Essential Dental Systems} U.S.A.

It is composed of BIS-GMA, titanium reinforced. Filler by weight is $75 \%$. It is radio-opaque.

\subsection{Preparation and Endodontic Treatment of Selected Teeth:}

All the forty-five samples were sectioned 2-mm coronal to the cemento-enamel junction with a wheel shaped diamond point on an air rotor with water spray. The teeth were prepared using a torpedo shaped diamond point above the cemento-enamel junction in such a way, to achieve a $2 \mathrm{~mm}$ ferrule (Yue LH, Xing ZY, 2003; Akkayan B. 2004; Pereira JF et al. 2006) and a 1.5mm deep chamfer finish margin (Akkayan B, Gulmez T, 2002).

Access opening of all 45 teeth was done with a round diamond point No.4 (Mani, Japan) at a high speed with water spray. At \#15 K-file was introduced into the canal to achieve patency of the canal. Pulp was extirpated with a barbed broach and constant irrigation with 5\% sodium hypochlorite.

Canal length was established using \#15 K file. Working length was kept $1 \mathrm{~mm}$ short of the apical end. Biomechanical preparation of the teeth was done with K-files from \#15 to \#60 using conventional technique. Frequent recapitulation was done to maintain patency of the canal and prevent it from getting clogged. Finally after proper biomechanical preparation, the canal was irrigated with distilled water and stored back in saline till obturation was done.

For obturation, each of the teeth was removed from saline, and the canal was dried with paper points. The canals of all the teeth were obturated using the same standardized process. Obturation was done with gutta-percha with a non-eugenol based root canal sealer. The gutta-percha at the canal orifice was sealed with a hot burnisher; samples were stored in saline (Akkayan B, Gulmez T, 2002). Eugenol is shown to inhibit polymerization of composite resin (Dilts WE, et al. 1986). Hence, a eugenol free root canal sealer was used in the study.

\subsection{Preparation of Post Space:}

The samples were removed from saline. A silicone stopper was attached to the universal drill, which was used to remove the gutta-percha and prepare the post space to a depth of $10 \mathrm{~mm}$ apical to the 
141 coronal dentin. The subsequent drills supplied by the manufacturer were used to further prepare the

142 post space to obtain the desired length and diameter for the specific posts. The canal was irrigated with 143 saline to remove debris.

144 The glass fiber posts selected were checked for their fit and length in the prepared canal. The 145 posts were cut $13 \mathrm{~mm}$ from its apical end to get the required dimensions, $10 \mathrm{~mm}$ in the tooth $(8 \mathrm{~mm}$ 146 below the cemento-enamel junction and $2 \mathrm{~mm}$ ferrule) and $3 \mathrm{~mm}$ above the prepared coronal dentin, 147 (Sirimani S, Riis DN, Morgano SM. 1999) (Figure-3).

148 An intra-oral periapical radiograph was taken to check the position of the post in the canal.

\section{2.5 Etching, Bonding, Silanation and Cementation:}

150

151

152 153

154

155

156

157

158

159

160

161

162

163

164

165

166

As instructed by the manufacturer silane was applied to the glass fiber post with a brush and air dried for $1 \mathrm{~min}$. Quartz fiber post is not required to be silanated. Zirconia posts were pre-silanated, but had to be cleaned with alcohol to remove any surface impurities. The post space and the exposed part of the coronal dentin was etched and primed for 10 seconds with Clearfil SE, then dried and Clearfil SE bonding agent was applied, after that it was exposed to a light blast of air to obtain a thin layer of bonding agent, which was then light cured for 20 seconds. All the 45 posts were bonded with Clearfil SE (Cohen BI. et at 1999).

RelyX ARC resin cement was used to cement the posts in the canals. Equal amounts of base and catalyst of RelyX ARC resin cement was mixed. The canal as well as the post was coated with it. The posts were placed in the canal and held under digital pressure, and light cured for 20 seconds.

All the posts in various groups were cemented in the similar manner.

\subsection{Composite core build up:}

A preformed core former was selected for each of the samples of the teeth for the core build-up with the respective core build-up materials. The core formers were modified at the gingival end to achieve the standard dimension of the core. Luxacore (DMG Dental Avenue India) is a dual cured core build-up material. 
167

168

169

170

171

172

173

174

175

176

177

178

179

180

181

182

183

184

185

186

187

188

189

190

191

192

193

194

Equal amount of base and catalyst was premixed and dispensed from the syringe into the core former. The core former with the core build-up material was placed on the post and prepared tooth surface. It was light cured for 40sec. The core formers were held in position for 5 minutes for complete polymerization to occur because it is a dual cured composite resin. In the similar manner all the core build-ups were carried out for the 15 samples using Luxacore.

Lumiglass (RTD France by Prime Dental India) is a light cured composite resin core build-up material.Ti-core (Essential Dental Systems U.S.A.) is a self-cured composite resin. It does not need to be light cured. In the similar manner all the core build-ups were carried out as mentioned above for the remaining 30 samples using Ti-core and Lumiglass. All above procedures were done by single operator/person.

\subsection{Mounting the samples:}

A split mould (Figure -1) was used to mount the teeth in autopolymerising acrylic resin. Petroleum jelly was applied on the inner surface of the split mould for easy separation of the acrylic block from the mould.

The teeth were mounted perpendicular to the base of the mould and embedded in the autopolymerising acrylic resin. The crown root ratio was not taken into consideration instead care was taken so that the cervical finish line was just above the auto-polymerising acrylic resin. All the teeth were mounted in a similar manner (Figure 3).

\subsection{Testing of the samples for fracture resistance:}

The acrylic block with the samples was placed on the Zwick machine for testing of the fracture resistance.

For positioning the samples on the Zwick machine a customized mounting fixture was fabricated into which the acrylic blocks fitted perfectly. The fixture also helps to position the samples in such a way that the load could be directed at $130^{\circ}$ to the long axis of the tooth (Akkayan B, Gulmez T, 2002) (Figure 2).

Each of the sample blocks were fixed to the base of the Zwick machine using the fixture and the tip of the plunger was made to contact the notch on the palatal surface of the core build up. The samples were loaded at a crosshead speed of $0.5 \mathrm{~mm} / \mathrm{min}$ (Fraga RC et al, 1998) until there was a 
195 visible or audible sign of failure in the post and core. The site at which the fracture took place was

196 evaluated and the results tabulated. Observations thus obtained were statistically analysed. 211 the other.

\section{Table-3.}

\section{RESULTS}

The study was carried out to assess the fracture resistance of various composite resin core build-up materials with three prefabricated non-metallic posts cemented in extracted endodontically treated teeth. The 45 specimens were loaded in the Zwick machine at an angle of $130^{\circ}$ to the long axis of the tooth. Load was applied till there was an audible or visible sign of fracture. The load at that instance was recorded as the peak load that the tooth can sustain before fracture. This was recorded for all the specimens and is listed in Table-2.

These observations were statistically analyzed to comparatively evaluate the values obtained. The analysis of variance ANOVA test was applied using F distribution. It is suitable for testing the significance of difference between two or more specimens simultaneously. Since significant F does not tell us which means are different from which other means, hence we had to proceed to test separate differences by permutation and combinations through student' $t$ ' test. The analysis of variance is based on a separation of the variance of all observation into parts, each of which measured variability attributable to some specific source such as internal variation of the specimen or one specimen from

Student unpaired ' $t$ ' test was also used to analyze and compare each group with the other groups individually, and decide whether their comparisons were statistically significant as listed in

Fracture patterns were either horizontal, oblique, some involving the core, some involving the post and tooth structure, some with debonding of post and core and some with a combination of above types. However an attempt is made to classify these fractures into two groups as shown in Table-4 and 5. They are -

1. Restorable or Salvageable Fractures:-

Fractures that have occurred above the CEJ, or oblique fractures that cross below the CEJ with sum amount of coronal dentin, and the oblique fracture ends in the cervical 1/3rd of the root. 
223 Fractures occurring below the CEJ with no coronal tooth structure remaining.

224 From $\boldsymbol{T a b l e}-3$ the following conclusions can be drawn as follows:

225 Group I-A does not differ with (Non-significant) Group II-A, Group III-A, Group I-B, Group I-C,

226 Group II-C but differs significantly with Group II-B, Group III-B, and Group III-C at P $<0.01$.

227 Group II-A does not differ with (Non significant) Group III-A, Group I-B, Group II-B, Group I-C, 228 Group II-C and differs significantly with Group III-B, Group III-C at $\mathrm{P}<0.01$.

229 Group III-A does not differ (Non significant) with Group I-B, Group II-C but differs significantly 230 with Group I-C at P $<0.05$, and Group II-B, Group III-B, Group III-C at P $<0.01$.

231 Group I-B does not differ (Non significant) with Group I-C, Group II-C but differs significantly with 232 Group II-B at $\mathrm{P}<0.05$ and Group III-B, Group III-C at $\mathrm{P}<0.01$.

233 Group II-B does not differ (Non significant) with Group II-B, Group I-C, Group II-C but differs 234 significantly with Group III-C at $\mathrm{P}<0.05$.

235 Group III-B does not differ (Non-significant) with Group III-C but differs significantly with Group I236 C, Group II-C at $\mathrm{P}<0.01$.

237 Group I-C does not differ (Non significant) with Group II-C and differs significantly with Group II-C 238 at $\mathrm{P}<0.01$.

239 Group II-C differs significantly with Group III-C at $\mathrm{P}<0.01$.

\section{Discussion}

The restoration of endodontically treated teeth has been a long concern of dentistry. These pulpally involved teeth, which were formally considered for extraction, are now being retained with the advances in the field of endododontics and restorative dentistry. Due to loss of tooth structure and altered physical characteristics following endodontic therapy, all teeth require some form of restorative treatment.

The longevity and the success of the endodontically treated teeth depend on the procedure with which it is restored. It has been observed that pulpless teeth are more brittle than vital teeth. Also 
anterior teeth are more prone to oblique forces resulting in horizontal and vertical fractures usually in the cervical third (Mclean JW, Gasser O. 1985). If there is a conservative access opening, no carious breakdown or fracture of tooth structure and no evidence of internal or external root resorption, the tooth can survive the brunt of masticatory load (Gutmann J.L. 1992). When there is excessive loss of tooth structure, retention for the artificial crown is required. This can be achieved by using a post and core (Morgano SM, Brackett SE. 1999). However, it should not adversely affect the load bearing capacity of the tooth. It has been indicated that the structural integrity of the tooth depends on the quality and quantity of dentin and its anatomic form (Gutmann J.L. 1992). When the tooth is endodontically treated both these factors are affected, hence they may not perform their function to their fullest extent as a vital tooth. Thus, an extra-coronal restoration would be required to restore the weakened tooth. The remaining tooth structure might not be adequate to retain a crown and thus, a post and core is indicated. A large number of post and core systems are available with their advantages and disadvantages. Conflicting results regarding the reinforcement of the tooth due to placement of post exists making it more difficult to choose a particular system (Assif D, Gorfil C. 1994).

There are various core materials used in the past like amalgam, glass ionomer cement, modified glass ionomer and composite resin. Prepared composite resins cores have better strength than prepared glass ionomer cement cores (Stober T, Rammelsberg P. 2005) and prepared amalgam cores.

A variety of self-cured, light cured and dual cured composite resin core build-up materials are used in conjunction with non-metallic posts for an aesthetic restoration (Standlee JP, Caputo AA, Hanson EL. 1978; Dilmener FT, Sipahi C, Dalkiz M. 2006).

In this study 45 extracted human maxillary central incisors were selected. The selection of intact natural central incisors seems to represent the best possible option to simulate clinical situation for endodontically treated anterior teeth. Previous studies have reported their use for research of various post systems (Akkayan B, Gulmez T. 2002; Fraga RC et al. 1998; Sirimani S, Riis DN, Morgano SM. 1999; Raygot CG, Chai J, Jameson L. 2001). An attempt was made to choose teeth of similar root length and diameter with the help of the digital vernier calliper. The mean size of roots was $15.41+1.18 \mathrm{~mm}$ in length and $6.29+0.45 \mathrm{~mm}$ in mesio-distal width at cemento-enamel junction.

All the samples were sectioned with an air rotor $2 \mathrm{~mm}$ coronal to cemento-enamel junction, and a finish line of $1.5 \mathrm{~mm}$ deep chamfer was prepared all around the samples. A ferrule of $2 \mathrm{~mm}$ was prepared for all the samples (Yue LH, Xing ZY. 2003; Pereira JF, Ornelas F, Conti PCR, Valle AL. 
279 2006; Akkayan B. 2004; Tan PLB et al. 2005). This was done to simulate the natural conditions, as 280 teeth which have fractured in the cervical one-third with insufficient coronal tooth structure remaining, 281 have to be restored with post and core so as to give retention to the artificial crown. A finish line of 1.5 $282 \mathrm{~mm}$ was given to simulate the preparation for the future extra-coronal restoration (Sirimani S, Riis DN, 283 Morgano SM. 1999).

The recommended diameter of posts used for restoring maxillary central incisors is between 0.9 to $1.4 \mathrm{~mm}$. Glass fiber has a diameter of $1.1 \mathrm{~mm}$, Quartz fiber $1.2 \mathrm{~mm}$ and Zirconia $1.2 \mathrm{~mm}$ have been used which are within the above mentioned range.

The length of the post below the cemento-enamel junction for maxillary central incisor is 8.3 $\mathrm{mm}$ according to Shillingburg HT, et al. in 1982. But for the ease of measurement in this study the posts were embedded to a depth of $8 \mathrm{~mm}$ below the cemento-enamel junction (Figure-3). The post head was exposed $3 \mathrm{~mm}$ above the ferrule for retention of the core build-up (Sirimani S, Riis DN, Morgano SM. 1999).

Composite resin core build-up materials have been widely used owing to their high compressive strength, good adhesive properties, low modulus of elasticity, and economically affordable (Piwowarczyk A et al.2002; Cohen BI et al.1996). From a variety of composite resin core materials available today, three materials were selected which were widely used. Luxacore, Lumiglass and Ti-core were the three composite resin core materials chosen, which have different modes of curing.

The core build-ups were modified with an air rotor to give the shape of a prepared tooth so as to simulate clinical conditions. The height of the core from the cemento-enamel junction was $8 \mathrm{~mm}$ (Brandal JL, Nicholls JI, Harrington GW, 1987). It was observed that the incisal edge of lower teeth contacted the palatal surface of the maxillary central incisor 1-mm below the incisal edge of the core (Dilmener FT, Sipahi C and Dalkiz M, 2006). Thus, this point was standardized for load application by preparing a notch on the palatal surface of the core 1-mm below the incisal edge. These samples were mounted on acrylic blocks.

The load was applied on the palatal aspect at an angle of $130^{\circ}$ to the long axis of the tooth. This was because the lower anterior teeth contacted the palatal surface of the upper anteriors at an angle of $130^{\circ}$ to the long axis of the maxillary central incisor. Guzy and Nicholl's reported that for incisors, a 
308 loading angle of $130^{\circ}$ was chosen to simulate a contact angle in Class I occlusion between maxillary 309 and mandibular anterior teeth (Guzy GE, Nicholls JI, 1979).

310 Crowns were not used in this study (Dilmener FT, Sipahi C and Dalkiz M, 2006; Burke FJT et 311 al 2000; Cohen BI, et al. 1997). It was observed that if the post and core combination has a good 312 fracture resistance, the addition of a crown would enhance the fracture resistance of the tooth and it 313 will be able to withstand greater forces (Kovarik et al. 1992; Kern SB, Fraunhofer JR, Mueninghoff A, 314 1984) In this manner the probable altering of parameters, such as material structure, shape, length, and 315 thickness, by crown restorations was avoided.

Load was applied by a Zwick universal load testing machine at a crosshead speed of 0.5 $\mathrm{mm} / \mathrm{min}$ (Fraga RC et al. 1998). Failure threshold was defined as a point at which the sample could no longer withstand load and fracture of material, tooth or root occurred (Figure-4). Loading to fracture represented a "worst case" scenario. Although it does not replicate what takes place in the oral environment, where teeth are subjected to forces of mastication that over a long period of time may cause fatigue resulting in tooth fracture (Baldissara $P$ et al. 2006). This method of testing has been widely used by previous researchers (Guzy GE et al. 1979; Martínez-Insua A et al. 1998; Pilo R et al. 2002).

Data thus obtained showed that Luxacore gave the highest mean fracture loads with all the three posts used.

The highest failure load was observed in a combination of zirconia post with Luxacore and lowest was observed in zirconia posts with lumiglass core build-up material. This is because zirconia is a much stronger post material than glass fiber and quartz fiber posts thus giving higher failure loads.

It was also observed that Luxacore provided only $73.33 \%$ salvageable fractures, whereas Lumiglass which is the weakest provided highest of $86.67 \%$ of salvageable fractures, and Ti-core provided $80 \%$ of salvageable fractures. Thus, the weaker the composite resin core build-up material, the earlier it will fracture at a lower load which would protect the tooth from fracturing(Kern SB, Fraunhofer JR, Mueninghoff A, 1984) and thus a restoration can be done again.

Glass fiber posts showed highest percentage of salvageable fractures of $93.33 \%$, while Quartz fiber and zirconia posts both showed lower percentage of salvageable fractures values of $73.33 \%$ each. 
Teeth which fractured above the cemento-enamel junction or just below the cemento-enamel junction in the coronal $1 / 3$ rd of the root with some amount of coronal dentin remaining were considered salvageable fractures (Akkayan B. 2004; Sidoli GE, King PA, Setchell DJ. 1997; Heydecke G et al. 2002; Toksavul Set al. 2005). There were non-salvageable fractures in zirconia posts due to their high modulus of elasticity due to which greater stresses were transmitted to the tooth causing its fracture (Akkayan B, Gulmez T. 2002).

Thus, Lumiglass has lowest fracture resistance than Ti-core and Luxacore, but produced maximum salvageable fractures, as the core would fracture before the tooth could fracture and failure would occur in the core rather than the tooth.

Glass fiber posts produced maximum number of salvageable fractures. This might be related to the fact that its modulus of elasticity is very close to dentin preventing transmission of undue stresses to the tooth.

$$
\text { Luxacore with zirconia and glass fiber posts have a failure load greater than the biting force. }
$$
But however these teeth would receive restoration, which would further enhance the fracture resistance (Akkayan B and Gulmez T 2002).

The results of the above study are in consistence with results obtained by Akkayan B and Gulmez T (2002). They concluded that there were more salvageable fractures in glass fiber posts than zirconia posts.

According to the study by Fraga RC, et al. (1998) concluded that there were more nonsalvageable fractures in cast post and core rather than metal posts with composite cores. They also observed that composite resin core build-ups are preferred because they will fracture at a lower load than what is required to fracture the tooth.

In earlier studies by Fokkinga WA, Kreulen CM, Vallittu P, Crugers NH (2004) showed that fiber reinforced posts had more failures than metal posts but there were more salvageable failures, whereas metal posts showed non- salvageable failures.

Composite resin core build up materials are less stiff and more resilient than metallic cores, thus transmitting lesser stresses to the tooth. Yaman and Thorsteinsson (1992) reported that stiffer core materials increases cervical stresses and reduces apical stresses. 
It was observed from the present study and the work done by other researchers, (Akkayan B,

365 Gulmez T. 2002; Raygot CG, Chai J, Jameson L. 2001; Heydecke G, et al. 2002) that a lot of 366 importance and emphasis is given to the strength of the posts, core and the restoration placed over 367 them. But going through literature, the load at which fracture of the teeth, post or core takes place is at 368 a much higher load than that actually occurring during mastication. It may be subjected to higher load 369 during a blow or trauma, which would lead to the fracture of the natural tooth. Therefore, the selection 370 of the post and core should be done on the basis of tooth structure loss, type of restoration placed after 371 the build-up and the occlusion it will be subjected to.

\section{Conclusion}

The study conducted evaluated the fracture resistance of three composite resin core build-up materials when used with three prefabricated posts cemented in extracted endodontically treated teeth. Within the limitation of the in-vitro study, the following conclusions were drawn, with glass fiber posts and least with quartz fiber posts.

379 then with quartz fiber posts and least with zirconia posts.

380 3. Ti-core (self-cured composite resin) had the best fracture resistance with quartz fiber posts then 381 with glass fiber posts and least with zirconia posts.

382 4. Luxacore showed the highest fracture resistance among the three core build-up materials with 383 all the three post systems followed by Ti-core and the least values were observed with lumiglass.

Fracture resistance of Luxacore was best with zirconia post, lumiglass was best with Glass fiber posts and Ti-core was best with Quartz fiber posts. The highest failure load was observed in a combination of zirconia post with Luxacore and lowest was observed in zirconia posts with lumiglass core build-up material.

388 5. a) It was observed that maximum number of salvageable fractures occurred with Lumiglass 389 followed by with Ti-core, and least occurred with Luxacore.

b) It was observed that maximum number of salvageable fractures occurred with glass fiber 391 post, while with both quartz fiber and zirconia posts same number of salvageable fractures occurred. 


\section{CONFLICT OF INTEREST \& SOURCE OF FUNDING:None}

394

395

396

397

398

399

400

401

402

403

404

405

406

407

408

409

410

411

412

\section{References:}

413 1. Akkayan B, Gulmez T. 2002. Resistance to fracture of endodontically treated teeth restored $414 \quad$ with different post systems. J Prosthet Dent 87:431-7. 
4152 2. Akkayan B. 2004. An in vitro study evaluating the effect of ferrule length on fracture resistance

416 of endodontically treated teeth restored with fiber reinforced and zirconia dowel systems. $J$ 417 Prosthet Dent 92:155-62.

418 3. Assif D, Gorfil C. 1994. Biomechanical consideration in restoring endodontically treated teeth. 419 J Prosthet Dent. 71:565-7.

420 4. Assif D, Oren D, Marshak DL, Aviv I. 1989. Photoelastic analysis of stress transfer by 421 endodontically treated teeth to the supporting structure using different restorative techniques. $J$ Prosthet Dent. 61:535-43.

5. Baldissara P, Di Grazia V, Palano A, Ciocca L. 2006. Fatigue resistance of restored endodontically treated teeth: a multiparametric analysis. Int J Prosthodont. 19(1):25-7

6. Brandal JL, Nicholls JI, Harrington GW. 1987. A comparison of three restorative techniques for endodontically treated anterior teeth. J Prosthet Dent. 58:161-5.

7. Burke FJT, Shaglouf AG, Combe EC, Wilson NHF. 2000. Fracture resistance of five pin retained core build-up materials on teeth with and without extracoronal preparation. Opera Dent. 25:388-94.

8. Cohen BI, Pagnillo MK, Condos S, Deutsch AS. 1996. Four different core materials measured for fracture strength in combination with five different designs of Endodontic posts. J Prosthet Dent. 76:487-95.

9. Cohen BI, Pagnillo MK., Newman I, Musikant BL, Deutsch AS. 1997. Cyclic fatigue testing of five Endodontic post designs supported by four core materials. J Prosthet Dent. 78:458-64.

10. Cohen BI., Pagnillo MK, Newman I, Musikant BL., Deutsch AS. 1999. Effects of three bonding systems on the torsional resistance of titanium reinforced composite cores supported by two post designs. J Prosthet Dent. 84:678-83.

11. Cohen S, Burns RC. 1994. Pathways of the Pulp. 6th Ed. The C.V. Mosby \& Co, 604-632.

12. Dilmener FT, Sipahi C and Dalkiz M. 2006. Resistance of three new esthetic post and core systems to compressive loading. J Prosthet Dent. 95:130-6.

13. Dilts WE, Miller RC, Miranda FJ, Duncanson MG. 1986. Effect of zinc oxide-eugenol of shear bond strengths of selected core/cement combinations. J Prosthet Dent. 55(2):206-8.

14. Fernandes AS, Dessai GS. 2001. Factors affecting the fracture resistance of post-core reconstructed teeth: a review. Int J Prosthodont 14:355-63.

15. Fernandes AS, Shetty S, Coutinho I. 2003. Factors determining post selection: A literature review. J Prosthet Dent. 90:556-62. 
447 16. Fokkinga WA, Kreulen CM, Vallittu P, Crugers NH. 2004. A structure analysis of in vitro

448

449

450

451

452

453

454

455

456

457

458

459

460

461

462

463

464

465

466

467

468

469

470

471

472

473

474

475

476

477

478

failure loads and failure modes of fiber, metal and ceramic post and core systems. Int $J$ Prosthodont 17:476-82.

17. Fraga RC, Chaves BT, Mello GSB, Siqueira JF. 1998. Fracture resistance of endodontically treated roots after restoration. J of Oral Rehab. 25:809-13.

18. Gutmann J.L. 1992. The dentin-root complex: Anatomic and biologic considerations in restoring endodontically treated teeth. J Prosthet Dent. 67:458-67.

19. Guzy GE, Nicholls JI. 1979. In vitro comparison of intact endodontically treated teeth with and without endo-post reinforcement. J Prosthet Dent. 42:39-43.

20. Guzy GE, Nichols JI. 1979. In vitro comparison of intact endodontically treated teeth with and without endo-post reinforcement. J Prosthet Dent. 42(1):39-44.

21. Heydecke G, Burtz F, Hussein A, Strub JR. 2002. Fracture strength after dynamic loading of endodontically treated teeth restored with different post and core systems. J Prosthet Dent. 87:438-45.

22. Kern SB, Fraunhofer JR, MueninghoffA. 1984. An in vitro comparison of two dowel and core techniques for endodontically treated molars. J Prosthet Dent. 51:509-14.

23. King PA, Setchell DJ. 1990. An in vitro evaluation of a prototype CFRC prefabricated post developed for the restoration of pulpless teeth. J Oral Rehab. 17:599-609.

24. Martínez-Insua A, da Silva L, Rilo B, Santana U. 1998. Comparison of the fracture resistances of pulpless teeth restored with a cast post and core or carbonfiber post with a composite core. $J$ Prosthet Dent. 80(5):527-32.

25. Mclean JW, Gasser O. 1985. Glass cermet cements. J Dent Res. 5:333-43.

26. Morgano SM, Brackett SE. 1999. Foundation restorations in fixed prosthodontics: Current knowledge and future needs. J Prosthet Dent. 82:643-54.

27. Pereira JF, Ornelas F, Conti PCR, Valle AL. 2006. Effect of a crown ferrule on the fracture resistance of endodontically treated teeth restored with prefabricated posts. J Prosthet Dent. 95:50-4.

28. Pilo R, Cardash HS, Levin E, Assif D. 2002. Effect of core stiffness on the in vitro fracture of crowned, endodontically treated teeth. J Prosthet Dent. 88(3):302-6.

29. Piwowarczyk A, Otti P, Lauer HL, Buchler A. 2002. Laboratory strength of glass ionomer cement, compomers and resin composites. J Prosthet Dent. 11:86-91. 
$47930 . \quad$ R. E. Kovarik, L. C. Breeding, W. F. Caughman. 1992. Fatigue life of three core materials $480 \quad$ under simulated chewing conditions. Journal of Prosthetic Dentistry, 68:584.

481 31. Raygot CG, Chai J, Jameson L. 2001. Fracture resistance and primary failure mode of 482 endodontically treated teeth restored with a carbon fiber reinforced resin post system in vitro.

32. Shetty T, Bhat S, Shetty P. July 2005. Aesthetic post materials A review article. JIPS. 5:122-5.

33. Shillingburg HT, Kessler JC, Wilson EL. 1982. Root dimensions and dowel size. Calif Dent Assoc J 10:43-9.

34. Sidoli GE, King PA, Setchell DJ. 1997. An in vitro evaluation of a carbon fiber based post and core system. J Prosthet Dent. 78:5-9.

35. Sirimani S, Riis DN, Morgano SM. 1999. An in vitro study of the fracture resistance and the incidence of vertical root fractures of pulpless teeth restored with six post and core systems. $J$ Prosthet Dent. 84:262-9.

36. Standlee JP, Caputo AA, Hanson EL. 1978. Retention of Endodontic dowels: Effects of cement dowel length, diameter and design. J Prosthet Dent. 39:401-5.

37. Stober T, Rammelsberg P. 2005. The failure rate of adhesively retained composite core buildups in comparison with metal added glass ionomer core build ups. J Dent 33:27-32.

38. Tan PLB, Aquilino SA, Gratton DG, Stanford CM, Tan SC, Johnson WT, Dawson D. 2005. In vitro fracture resistance of endodontically treated central incisors with varying ferrule heights and configurations. J Prosthet Dent. 93:331-6.

39. Toksavul S, Toman M, Uyulgan, Schmage P, Nergiz I. 2005. Effect of luting agent and reconstruction techniques on the fracture resistance of prefabricated post systems. $J$ of Oral Rehab. 32:433-440.

40. Torbjorner A, Karlsson S, Odman PA. 1995. Survival rate and failure characteristics for two post designs. J Prosthet Dent 73:439-44.

41. Trabert KC, Cooney JP. 1984. The endodontically treated tooth. Dent Clin North Am 28:92351.

42. Yue LH, Xing ZY. 2003. Effect of post-core design and ferrule on fracture resistance of endodontically treated maxillary central incisors. J Prosthet Dent. 89:368-73. 
1

Photograph showing split mould for mounting samples

Fig 1 - Photograph showing split mould for mounting samples

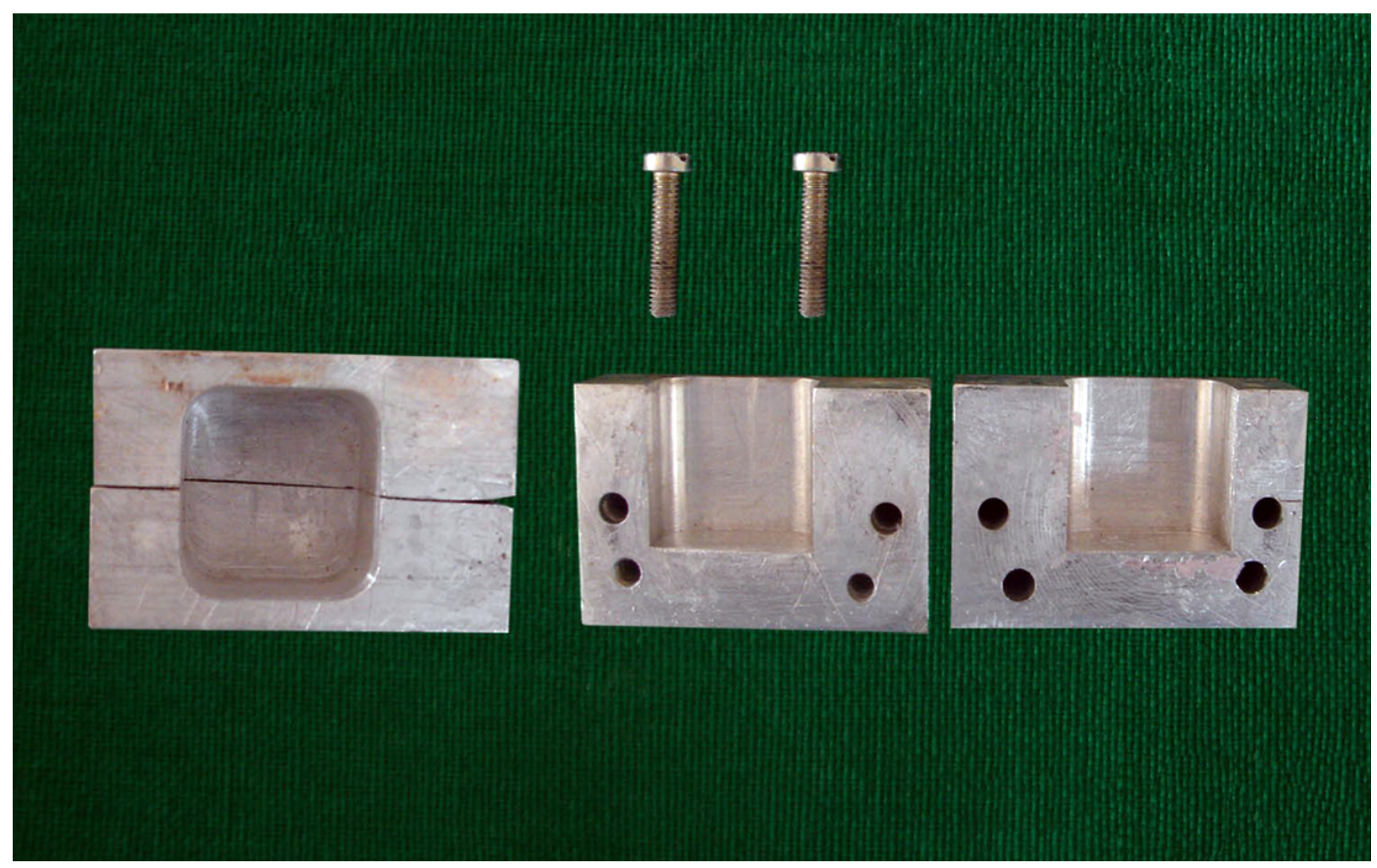


2

Photograph showing samples positioned at $130^{\circ}$ on the Zwick universal load testing machine

Fig 2 - Photograph showing samples positioned at $130^{\circ}$ on the Zwick universal load testing machine

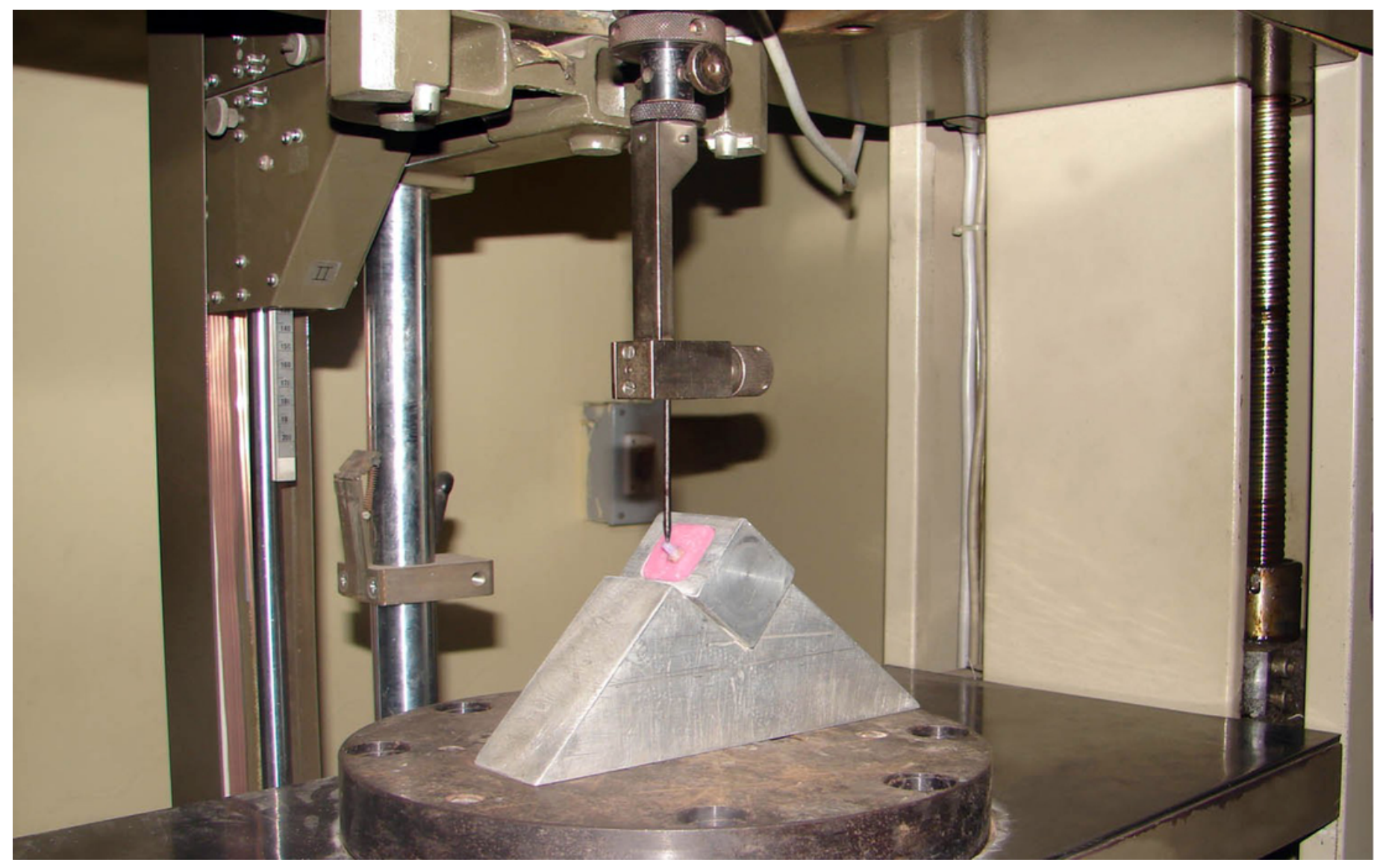


3

Photograph showing dimensional representation of post and core foundation

Fig 3 - Photograph showing dimensional representation of post and core foundation

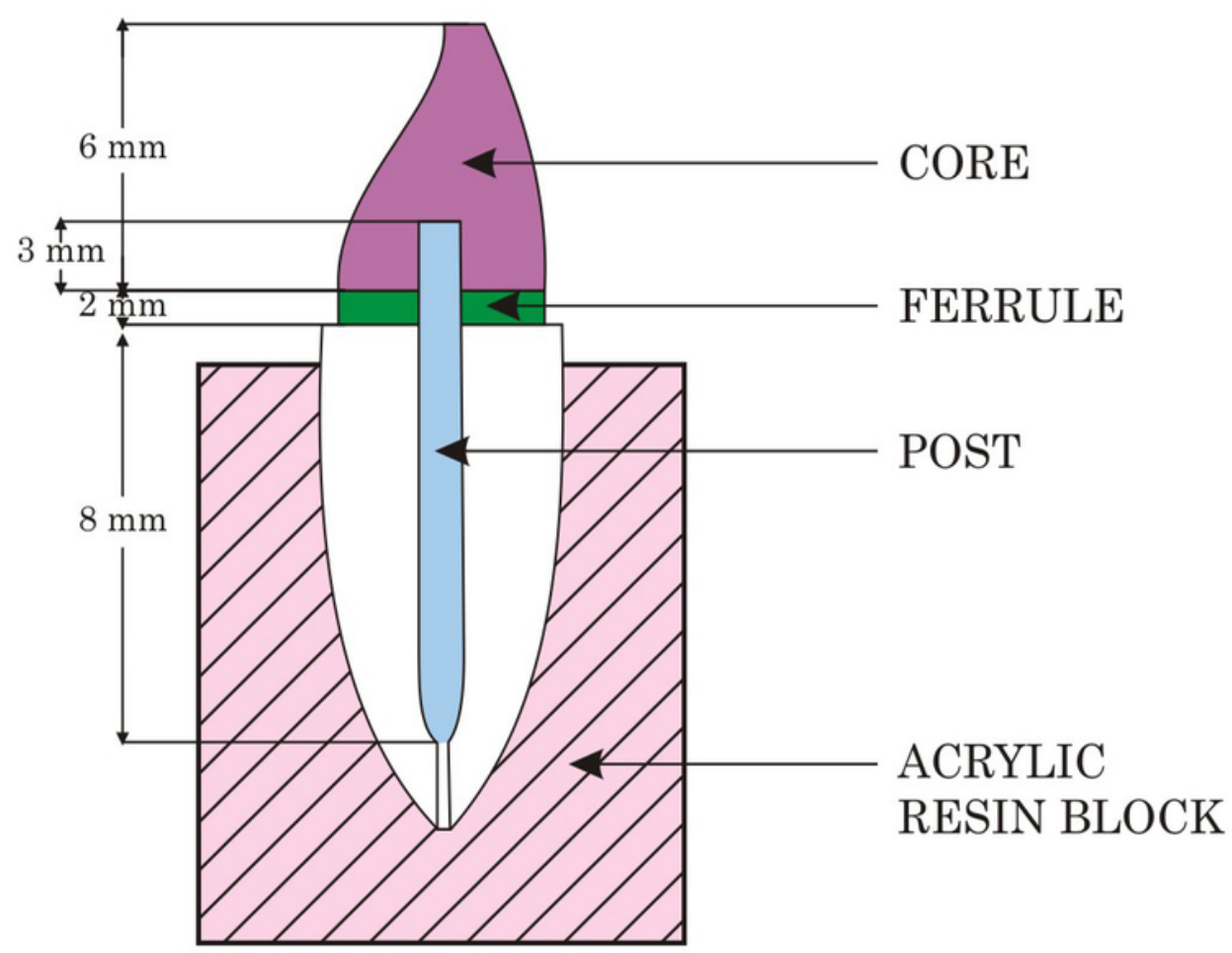


4

Photograph showing fractured samples

Fig 4 - Photograph showing fractured samples

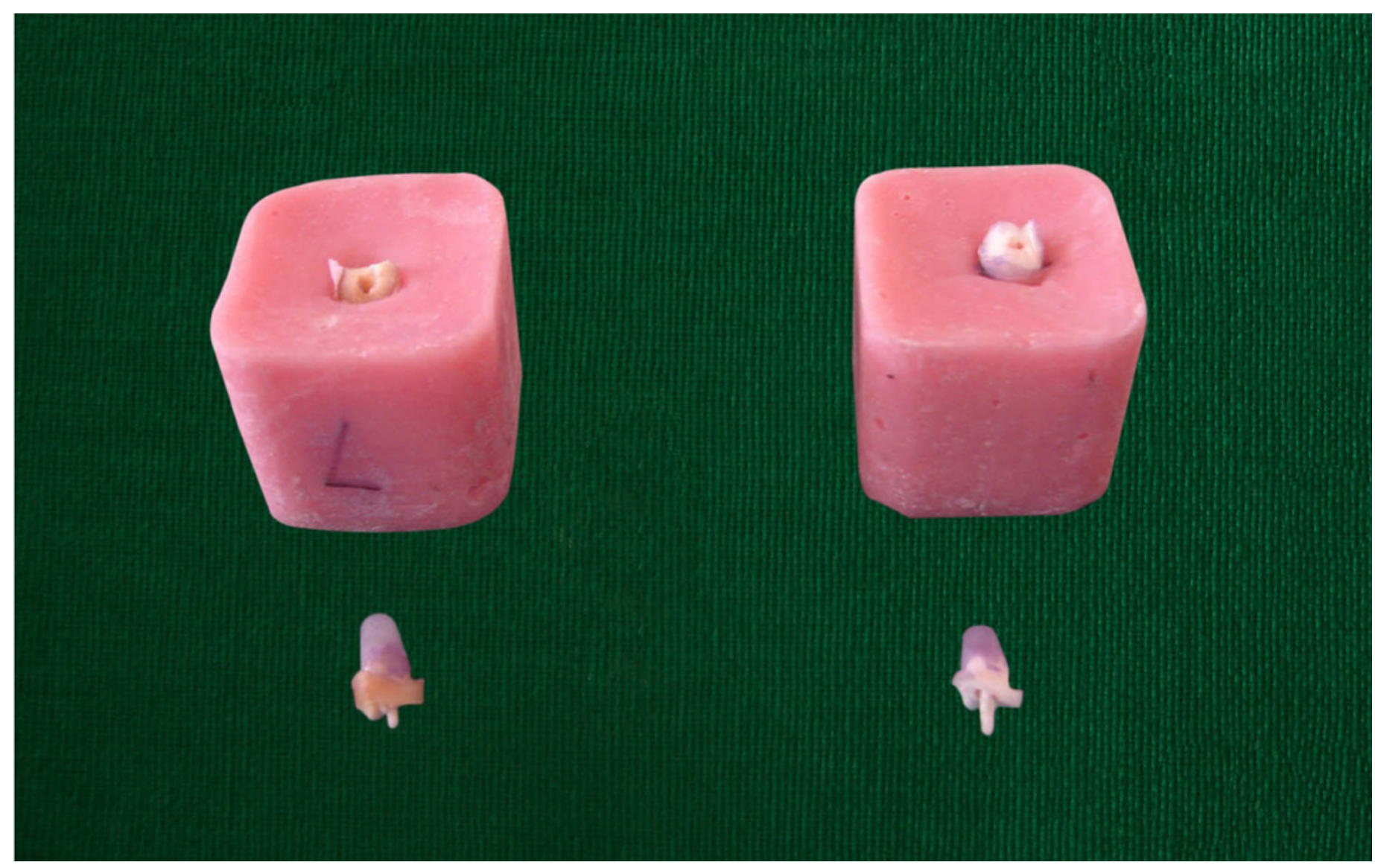


Table $\mathbf{1}$ (on next page)

Table showing 45 teeth divided into total of 9 subgroups having 5 samples each

Table 1 - Table showing 45 teeth divided into total of 9 subgroups having 5 samples each 
TABLE-1

The Samples Were Divided Into Total of 9 Subgroups Having 5 Samples Each

\begin{tabular}{|c|c|c|c|}
\hline & & & Sub Groups \\
\hline \multirow{3}{*}{$\begin{array}{c}\text { Group } \\
\text { I }\end{array}$} & \multirow{3}{*}{$\begin{array}{l}\text { (Reforpost by Angelus } \\
\text { Dental solutions Brazil). }\end{array}$} & A - Luxacore & I-A Glass Fiber post+ Luxacore \\
\hline & & B - Lumiglass & I-B Glass Fiber post + Lumiglass \\
\hline & & C - Ti Core & I-C Glass Fiber post + Ti Core \\
\hline \multirow{3}{*}{$\begin{array}{c}\text { Group } \\
\text { II }\end{array}$} & \multirow{3}{*}{$\begin{array}{l}\text { ( D.T. Light posts by } \\
\text { RTD France) }\end{array}$} & A - Luxacore & II-A Quartz Fiber post+ Luxacore \\
\hline & & B - Lumiglass & II-B Quartz Fiber post+ Lumiglass \\
\hline & & C-Ti Core & II-C Quartz Fiber post+ Ti Core \\
\hline \multirow{3}{*}{$\begin{array}{c}\text { Group } \\
\text { III }\end{array}$} & \multirow{3}{*}{$\begin{array}{c}\text { (Snow light posts by } \\
\text { Danville) }\end{array}$} & A - Luxacore & III-A Zirconia post + Luxacore \\
\hline & & B - Lumiglass & III-B Zirconia post + Lumiglass \\
\hline & & C - Ti Core & III-C Zirconia post + Ti Core \\
\hline
\end{tabular}

4

5

6

7

8

9

10

11

12 
53

54

55

56

57

58

59

60

61

62

63

64

65

66

67

68

69

70

71

72

73

74

75

76

77

78 
Table 2 (on next page)

Failure loads for all the Specimens in various groups

TABLE 2 - Failure Loads for All the Specimens in Various Groups 
TABLE-2

Failure Loads for All the Specimens in Various Groups

5

6

\begin{tabular}{|c|c|c|c|c|c|c|c|c|c|}
\hline $\begin{array}{c}\text { Group } \\
\text { INDICES }\end{array}$ & I-A & II-A & III-A & I-B & II-B & III-B & I-C & II-C & III-C \\
\hline SAMPLE SIZE & 5 & 5 & 5 & 5 & 5 & 5 & 5 & 5 & 5 \\
\hline MEAN & 25.220 & 23.115 & 26.010 & 23.614 & 19.896 & 16.873 & 22.163 & 22.715 & 15.498 \\
\hline STANDARD & & & & & & & & & \\
DEVIATION \pm & \pm 1.4006 & \pm 3.0814 & \pm 3.3845 & \pm 2.8105 & \pm 3.2506 & \pm 1.9118 & \pm 2.2128 & \pm 3.6613 & \pm 3.3860 \\
(S.D.) & & & & & & & & & \\
\hline RANGE & $23.593-$ & $20.134-$ & $22.238-$ & $20.780-$ & $16.603-$ & $15.035-$ & $19.055-$ & $19.497-$ & $11.264-$ \\
& 26.981 & 27.851 & 29.531 & 27.916 & 24.072 & 19.236 & 24.310 & 28.977 & 19595 \\
\hline
\end{tabular}

7

8

9

10 
Table 3 (on next page)

Mean Difference between Pairs of Groups with its Significance using Students 't' test

TABLE 3 - Mean Difference Between Pairs Of Groups With Its Significance Using Students ' $t$ ' Test 
TABLE-3

Mean Difference Between Pairs Of Groups With Its Significance Using Students ' $t$ ' Test

\begin{tabular}{|c|c|c|c|c|c|c|c|c|c|}
\hline & I-A & II-A & III-A & I-B & II-B & III-B & I-C & II-C & III-C \\
\hline I-A & - & $\begin{array}{c}2.105 \\
\text { NS }\end{array}$ & $\begin{array}{c}0.790 \\
\mathrm{NS}\end{array}$ & $\begin{array}{c}1.606 \\
\text { NS }\end{array}$ & $\begin{array}{c}5.324 \\
* * \\
\end{array}$ & $\begin{array}{c}8.347 \\
* *\end{array}$ & $\begin{array}{c}3.050 \\
\text { NS }\end{array}$ & $\begin{array}{c}2.505 \\
\mathrm{NS} \\
\end{array}$ & $\begin{array}{c}9.722 \\
* *\end{array}$ \\
\hline II-A & - & - & $\begin{array}{c}2.895 \\
\text { NS }\end{array}$ & $\begin{array}{c}0.497 \\
\text { NS }\end{array}$ & $\begin{array}{c}3.219 \\
\text { NS }\end{array}$ & $\begin{array}{c}6.242 \\
* *\end{array}$ & $\begin{array}{c}0.952 \\
\mathrm{NS}\end{array}$ & $\begin{array}{c}0.400 \\
\text { NS }\end{array}$ & $\begin{array}{c}7.617 \\
* *\end{array}$ \\
\hline III-A & - & - & - & $\begin{array}{c}2.396 \\
\text { NS }\end{array}$ & $\begin{array}{c}6.114 \\
* *\end{array}$ & $\begin{array}{c}9.137 \\
* *\end{array}$ & $\begin{array}{c}3.847 \\
*\end{array}$ & $\begin{array}{c}3.295 \\
\text { NS }\end{array}$ & $\begin{array}{c}10.512 \\
* *\end{array}$ \\
\hline I-B & - & - & - & - & $\begin{array}{c}3.718 \\
*\end{array}$ & $\begin{array}{c}6.741 \\
* *\end{array}$ & $\begin{array}{c}1.001 \\
\text { NS }\end{array}$ & $\begin{array}{c}0.899 \\
\text { NS }\end{array}$ & $\begin{array}{c}8.116 \\
* *\end{array}$ \\
\hline II-B & - & - & - & - & - & $\begin{array}{c}3.023 \\
\mathrm{NS}\end{array}$ & $\begin{array}{c}2.267 \\
\text { NS }\end{array}$ & $\begin{array}{c}2.819 \\
\text { NS }\end{array}$ & $\begin{array}{c}4.398 \\
*\end{array}$ \\
\hline III-B & - & - & - & - & - & - & $\begin{array}{c}5.290 \\
* *\end{array}$ & $\begin{array}{c}5.842 \\
* *\end{array}$ & $\begin{array}{c}1.375 \\
\text { NS }\end{array}$ \\
\hline I-C & - & - & - & - & - & - & - & $\begin{array}{c}0.552 \\
\text { NS }\end{array}$ & $\begin{array}{c}6.665 \\
* *\end{array}$ \\
\hline II-C & - & - & - & - & - & - & - & - & $\begin{array}{c}7.217 \\
* *\end{array}$ \\
\hline III-C & - & - & - & - & - & - & - & - & - \\
\hline
\end{tabular}

N.S. - Non Significant $\mathrm{P}>0.05$

* $\quad$ - Significant $\mathrm{P}<0.05$

** $\quad$ - Significant $\mathrm{P}<0.001$

Table Value of ' $t$ ' for 36 degree of freedom $(d f)$

$$
\text { t } 0.05=2.02
$$$$
\text { t } 0.001=2.436
$$

S.E. $\mathbf{D}=2.8828 \sqrt{1 / 5}+1 / 5=1.8231$

D $0.05=2.028 \times 1.8231=3.7155$

D $0.001=2.436 \times 1.8231=44630$

Largest difference is between III-A - III-C $=26.010-15.498=10.512$

Smallest difference is between II-A - II-C $=23.115-22.715=0.400$

17 differences are significant at 0.05 level

14 differences are significant at 0.01 level. 
Table 4 (on next page)

The number of specimens fractured as salvageable or Non-salvageable in all the groups with respect to core material used

TABLE 4 -The Number Of Specimens Fractured As Salvagable Or Non-Salvageable In All The Groups With Respect To The Core Material Used 
TABLE-4

3

4 5 6

\section{The Number Of Specimens Fractured As Salvagable Or Non-Salvageable In All The Groups With Respect To The Core Material Used}

\begin{tabular}{|c|c|c|c|c|}
\hline \multirow{2}{*}{ GROUP } & \multicolumn{2}{|c|}{ Salvagable Fractures } & \multicolumn{2}{c|}{ Non-salvagable Fractures } \\
\cline { 2 - 5 } & Nos. & $\%$ & Nos. & $\%$ \\
\hline I-A & 4 & 26.67 & 1 & 6.66 \\
\hline II-A & 3 & 20.00 & 2 & 13.33 \\
\hline TII-A & 4 & 26.67 & 1 & 6.66 \\
\hline I-B & 11 & 73.33 & 4 & 26.66 \\
\hline II-B & 5 & 33.33 & - & - \\
\hline III-B & 5 & 33.33 & - & - \\
\hline TOTAL: & 3 & 20 & 2 & 13.33 \\
\hline I-C & 13 & 86.66 & 2 & 13.33 \\
\hline II-C & 5 & 33.33 & - & - \\
\hline III-C & 3 & 20.00 & 2 & 13.33 \\
\hline TOTAL: & 4 & 26.67 & 1 & 6.66 \\
\hline GRAND TOTAL : & 12 & 80 & 3 & 20 \\
\hline
\end{tabular}

9 
Table 5(on next page)

Number of Specimens fractured as salvageable or Non-salvageable in all the groups with respect to the Posts used

TABLE 5 - Number Of Specimens Fractured As Salvageable Or Non-Salvageable In All The Groups Respect To The Posts Use d 
TABLE-5

Number Of Specimens Fractured As Salvagable Or Non-Salvagable In All The Groups Respect To The Posts Used

\begin{tabular}{|c|c|c|c|c|c|}
\hline \multirow{2}{*}{\multicolumn{2}{|c|}{ GROUP }} & \multicolumn{2}{|c|}{ Salvagable Fractures } & \multicolumn{2}{|c|}{ Non-salvagable Fractures } \\
\hline & & Nos. & $\%$ & Nos. & $\%$ \\
\hline \multirow{3}{*}{ (I) } & $\mathbf{A}$ & 4 & 26.67 & 1 & 6.67 \\
\hline & B & 5 & 33.33 & - & - \\
\hline & $\mathbf{C}$ & 5 & 33.33 & - & - \\
\hline \multicolumn{2}{|c|}{ TOTAL :( $15=100 \%)$} & 14 & 93.33 & 1 & 6.67 \\
\hline \multirow{3}{*}{ (II) } & $\mathbf{A}$ & 3 & 20 & 2 & 13.33 \\
\hline & $\mathbf{B}$ & 5 & 33.33 & - & - \\
\hline & $\mathbf{C}$ & 3 & 20 & 2 & 13.33 \\
\hline \multicolumn{2}{|c|}{ TOTAL: $(15=100 \%)$} & 11 & 73.33 & 4 & 26.67 \\
\hline \multirow{3}{*}{ (III) } & A & 4 & 26.67 & 1 & 6.67 \\
\hline & $\mathbf{B}$ & 3 & 20 & 2 & 13.33 \\
\hline & $\mathbf{C}$ & 4 & 26.67 & 1 & 6.67 \\
\hline \multicolumn{2}{|c|}{ TOTAL: $(15=100 \%)$} & 11 & 73.33 & 4 & 26.67 \\
\hline \multicolumn{2}{|c|}{ GRAND TOTAL $(45=100 \%)$} & 36 & 80.0 & 9 & 20.0 \\
\hline
\end{tabular}

